\title{
FAKTOR - FAKTOR YANG MEMPENGARUHI KEPUTUSAN WANITA MUSLIM DI WILAYAH TANGGERANG SELATAN BERWIRAUSAHA
}

\author{
Cut Erika Ananda Fatimah \\ UIN Syarif Hidayatullah Jakarta \\ cut.erika@uinjkt.ac.id
}

\begin{abstract}
This paper empirically examined the Analysis factors that influences of decisions to be Entrepreuner at Moslem Women Entrepreuner in South Region in Tanggerang. The analysis factors of influences of decisions factors is intended to determne whether among interests, motivations, families support, financial resources and information technology. The study utilizes a review of litelatures to purpose a conceptual model. The model is tested with data from survey among 60 moslem women in South region of Tanggerang using Factor Analysis Technique. The dimension of this The results confirm that the first factor is dominated by the internet facilities, social media, information technology expand the network and the use of information technology reduces the cost of the efforts of women entrepreneurs in the moslem women in South region of Tanggerang.
\end{abstract}

Keywords : Analysis of factors (interests, motivations, families support, financial resources and information technology), decisions, entrepreuner, moslem women

Abstract. Penelitian ini secara empiris meneliti analisis faktor yang mempengaruhi keputusan untuk menjadi Entrepreuner di Moslem Women Entrepreuner di Kawasan Selatan di Tanggerang. Faktor analisis pengaruh faktor keputusan dimaksudkan untuk determne apakah antara kepentingan, motivasi, keluarga dukungan, sumber daya keuangan dan teknologi informasi. Penelitian ini menggunakan review dari litelatures untuk tujuan model konseptual. Model ini diuji dengan data dari survei di antara 60 perempuan muslim di wilayah Selatan dari Tanggerang menggunakan Teknik Analisis Faktor. Dimensi ini Hasil mengkonfirmasi bahwa faktor pertama didominasi oleh fasilitas internet, media sosial, teknologi informasi memperluas jaringan dan penggunaan teknologi informasi mengurangi biaya usaha pengusaha perempuan pada wanita muslim di wilayah Selatan dari Tanggerang .

Kata Kunci: Analisis faktor (kepentingan, motivasi, keluarga dukungan, sumber daya keuangan dan teknologi informasi), keputusan, Entrepreuner, wanita muslim. 


\section{PENDAHULUAN}

Pembangunan dijalankan oleh suatu negara, merupakan bagian dari mempercepat pertumbuhan dan perkembangan perekonomian di suatu negara, yang tidak dapat dilepas, yaitu peranan pengusaha swasta besar, menengah maupun kecil.Peranan wirausaha dalam pembangunan, adalah dapat menyerapnya tenaga kerja yang banyak dan perputaran uang yang besar dan cepat, serta mendukungan pertumbuhan dan perkembangan barang dan jasa yang sesuai dengan kebutuhan dan keinginan manusia. Dapat dikatakan bahwa wirausaha merupakan pejuang bangsa di bidang pembangunan ekonomi, karena dapat meningkatkan ketahanan nasional, dan mengurangi ketergantungan dari negara lain.

Siapapun saat ini dapat mendukung pembangunan. Majunya perekonomian Indonesiasaat ini dalam bidang wirausaha tidak hanya dimiliki oleh para lelaki tetapi sejak adanya emansipasi wanita, wanita pun mulai tergerak untuk membuat suatu usaha yang dapat dijadikan tumpuan hidupnya kelak atau sebagai pekerjaan sampingan untuk membantu membiayai kehidupan keluarganya serta sebagai bukti bahwa wanita mampu berdiri dikaki sendiri.

Data Badan Pusat Statistik (BPS) pada tahun 2011, dari 230 juta penduduk Indonesia berdasarkan komposisi gender, terdiri dari 119.5 juta berkelamin pria dan 118 juta adalah wanita. Setiap tahunnya rasio perbandingan ini terus meningkat, 58\% di antaranya menempati Pulau Jawa yang mempunyai luas wilayah hanya 7\%.

Wanita merupakan aset yang begitu besar dalam pembangunan, namun kenyataannya belum dimanfaatkan secara optimal.Dalam bidang perekonomian partisipasi wanita ternyata masih sangat rendah. Data dari Kementrian Pemberdayaan Perempuan menunjukkan bahwa partisipasi angkatan kerja perempuan relatif kecil sekitar 51\% dan umumnya bekerja disektor informal dengan upah yang sangat rendah, hal ini menggambarkan pemberdayaan perempuan dalam pembangunan masih rendah (Jawa Pos, 26/12/2003 dalamUlfiPristiana, 2003). Di sisi lain kita dapat melihat perkembangan yang terjadi di tahun 2011, data yang diperoleh dari Kementrian Koperasi dan Usaha Kecil serta Menengah (Kemenkop dan UKM) mencatat data, bahwa saat ini ada $39 \%$ atau 53,8 juta pelaku usaha mikro kecil dan menengah (UMKM) diseluruh Indonesia, sebanyak 21 juta adalah UMKM yang dikelola oleh wanita. (madina.co.id/index.php/ekonomi) 
Sektor wirausaha, dapat mengembangkan pertumbuhan perekonomian di kawasan yang baru saja dimekarkan oleh pemerintah, salah satu wilayah yang independen menjadi propinsi baru di Indonesia adalah Banten. Wilayah propinsi Banten terdiri dari empat kota yaitu kabupaten Pandeglang lebak, Tangerang, Serang, dan Kota Tanggerang, Tangerang Selatan, Cilegon dan Serang. Kota Tanggerang Selatan merupakan wilayah dengan luas terkecil 147, $19 \mathrm{~km} 2$, sebagian besar penduduk memeluk agama Islam yaitu sebanyak 90,98\%. Penduduk selebihnya memeluk agama Protestan (4,07\%), Kristen (3,14\%), Budha (1,21\%) dan Hindu (0,60\%). (www.tangerangselatankota.go.id).

Salah satu potensi Kota Tangerang Selatan adalah letak geografisnya yang strategis. Letak geografis Kota Tangerang Selatan yang berbatasan dengan Provinsi DKI Jakarta pada sebelah Utara dan Timur memberikan peluang pada Kota Tangerang Selatan sebagai salah satu daerah penyangga Provinsi DKI Jakarta, selain itu juga sebagai daerah yang menghubungkan Provinsi Banten dengan Provinsi DKI Jakarta. Selain itu, Kota Tangerang Selatan juga sebagai salah satu daerah yang menghubungkan Provinsi Banten dengan Provinsi Jawa Barat.Walaupun merupakan wilayah dengan luas terkecil di Propinsi Banten, Tanggerang Selatan adalah wilayah dengan kepadatan penduduk yang tinggi,. Kepadatan penduduk ini disebabkan peningkatan jumlah dari waktu ke waktu selain peningkatan secara alami dan faktor daya tarik wilayah yang berdampingan langsung dengan kota DKI Jakarta dan menjadi wilayah limpahan penduduk kota Jakarta (data riset IPB). Hal ini dapat menyebabkan gairah investasi di Tangerang Selatan dan pengembangan wirausaha di wilayah ini dapat ditingkatkan jika daerah memiliki potensi, baik itu berupa potensi sumber daya alam maupun sumber daya manusia. Hal lain yang juga sangat penting adalah kemampuan daerah menjual potensi yang dimilikinya dan menciptakan iklim usaha yang kondusif. Tangerang Selatan dipimpin oleh seorang walikota wanita, yang memiliki visi untuk mengembangkan dunia usaha di Tangsel. Adapun data yang terkait dengan jumlah ketenagakerjaan di Tanggerang selatan, dapat dilihat dari tabel berikut : 
Tabel Indikator Ketenagakerjaan Kota Tangerang Selatan Menurut Jenis Kelamin Tahun 2010

\begin{tabular}{|l|r|r|r|}
\hline \multicolumn{1}{|c|}{ Karakteristik } & \multicolumn{1}{|c|}{ Laki-laki } & Perempuan & \multicolumn{1}{c|}{$\begin{array}{c}\text { Laki-laki + } \\
\text { Perempuan }\end{array}$} \\
\hline \multicolumn{1}{|c|}{$(1)$} & \multicolumn{1}{c|}{$(2)$} & \multicolumn{1}{c|}{$(3)$} & \multicolumn{1}{c|}{$(4)$} \\
\hline 1. Penduduk Usia Kerja & 415782 & 194428 & 610210 \\
\hline 2. Angkatan Kerja & 386156 & 173922 & 560078 \\
\hline a. Bekerja & 29626 & 20506 & 50132 \\
\hline b. Pengangguran & 103750 & 303031 & 406781 \\
\hline 3. Bukan Angkatan Kerja : & 85538 & 298912 & 384450 \\
\hline a. Sekolah dan Mengurus RT & 18212 & 4119 & 22331 \\
\hline b. Lainnya & 80,03 & 39,08 & 60,00 \\
\hline 4. Tingkat Partisipasi Angkatan Kerja (\%) & 7,13 & 10,55 & 8,22 \\
\hline 5. Tingkat Pengangguran Terbuka (\%) & 92,87 & 89,45 & 91,78 \\
\hline 6. Tingkat Kesempatan Kerja (\%) & & & 101691 \\
\hline
\end{tabular}

Sumber: BPS Kota Tangerang Selatan

Seiringan dengan keinginan Gubernur Banten, seperti dikutip dalam website ekonomi.kompasiana.com/wirausaha/2011/. Gubernur memprioritaskannya perempuan karena perempuan selama ini menjadi pengatur belanja rumah tangga. Ironisnya, saat ini perempuan sangat tergantung pada sumber-sumber keuangan alternatif seperti hibah program pengentasan kemiskinan baik yang dilakukan pemerintah maupun lembaga-lembaga sosial dan LSM, rentenir, kerabat, tetangga dan sebagainya. Mereka sangat tergantung pada usaha tidak berkesinambungan sehingga terjerat hutang dan kesulitan. Oleh karena itu, Pemerintah Propinsi Banten mengalokasikan anggaran dan melaksanakan kegiatan pembinaan serta memfasilitasi penguatan modal bagi UMKM. Nilainya bisa mencapai Rp 10 juta per UMKM, untuk saat ini totalnya ada 882 ribu UMKM di propinsi Banten.

Berdasarkan alasan di atas penelitian ini dilakukan sehingga dapat diketahui apa yang menyebabkan wanita muslim mengambil keputusan berwirausaha terutama di Tanggerang selatan, kenapa wirausaha muslim yang dipilih, disebabkan data menggambarkan populasi agama terbesar di Tanggerang Selatan adalah Islam, dan 
dengan harapan dapat dikembangkan sebagai motivator bagi setiap wanita di Indonesia yang juga mayoritas masyarakat Islam dalam mengambil keputusan sebagai wirausaha. Bank Negara Indonesia (BNI) menemukan fenomena yang terjadi empat tahun terakhir, bahwa terjadi lonjakan perempuan yang berwirausaha, lebih dari 40 persen. BNI mencatat, dari sekitar 58.000 usaha kecil, 25 persennya (sekitar 12.000) dijalankan oleh perempuan. (galeriukm.com)

Lebih lanjut lagi, Allah SWT menggariskan bahwa seorang Muslim harus berusaha menemukan rezekinya. Allah SWT menyenangi Muslim yang gigih menemukan rezkinya dan mau berpayah-payah. Allah SWT memberi rezeki kepada hamba-Nya sesuai dengan kegiatan dan kemauan keras serta ambisinya (HR AthThusi). (Kelana, 2008:3)

Seorang Muslimah sudah menjadi kewajibannya untuk mendukung keluarganya dalam mencari rezeki, seperti yang di contohkan oleh Siti Khadijah isteri Rasulullah SAW. Beliau merupakan suri teladan sempurna bagi seluruh perempuan di dunia. Satu hal menarik yang sering menjadi sorotan dari sosok Siti Khadijah, yaitu kenyataan bahwa ia adalah seorang business woman sukses pertama di Arab pada masa itu dengan kekayaan melimpah ruah, serta perniagaan di mana-mana. Atas keberhasilannya ini, ia pun dijuluki “Ratu Quraisy” juga "Ratu Mekkah”. (Ziyad : 2013)

Kewirausahaan adalah langkah untuk memperjuangkan kehidupan yang lebih layak bagi setiap manusia, dan kaum muslim khususnya wanita muslim, dapat menambahkannya menjadi keberkahan finansial yang dapat membantu keluarganya dan juga membantu masyarakat umumnya sehingga medapatkan keberkahan dari Allah SWT.

Kewirausahaan tidak hanya dapat digunakan sebagai kiat-kiat bisnis jangka pendek, tetapi juga sebagai kiat untuk bertahan hidup secara umum dalam jangka panjang. (Suryana 2013:3). Sedangkan wirausaha (entrepreneur) adalah seorang yang menciptakan bisnis baru dengan mengambil resiko dan ketidakpastian demi mecapai keuntungan dan pertumbuhan dengan cara mengidentifikasi peluang yang signifikan dan menggabungkan sumber-sumber daya yang diperlukan untuk dapat dikapitaliskan. (Zimerrer, Scarborough 2008:4)

Karakteristik individual di antara para pengusaha yang telah dipelajari adalah gender dan terdapat pertumbuhan yang signifikan dalam jumlah pekerja bebas 
wanita, dengan para wanita yang saat ini memulai usaha-usaha baru pada kecepatan yang lebih tinggi apabila dibandingkan kaum pria. Menurut Hisrich (2008:83), pengusaha wanita memiliki perbedaan dalam hal motivasi, ketrampilan bisnis, dan latar belakang pekerjaan. Wanita cendrung termotivasi oleh kebutuhan untuk prestasi yang berasal dari rasa frustasi terhadap pekerjaan karena tidak diperkenankan untuk bekerja dan tumbuh dalam situasi pekerjaan mereka yang sebelumnya. Wanita memulai usahanya sebagai sebuah pencarian pribadi. Lebih lanjut lagi menurut Hisrich wanita memulai usahanya di dukung oleh teman-teman dekat, suami, keluarga, kelompok profesional wanita dan asosiasi pedagangan lainnya dan mereka banyak bergerak dalam bidang yang berhubungan dengan jasa, ritel, hubungan masyarakat dan jasa pendidikan.

Menurut Brown dan Brooks (1991 : 82) minat adalah kecenderungan untuk memperhatikan dan menyukai beberapa hal atau kegiatan, khususnya terhadap hal tertentu. Kegiatan yang diminati seseorang harus diperhatikan terus menerus yang disertai dengan rasa senang, sehingga diperoleh kepuasan. Lebih lanjut lagi, minat berwirausaha tidak dibawa sejak lahir tapi tumbuh dan berkembang sesuai dengan faktor-faktor yang mempengaruhi. Faktor yang memengaruhi tumbuhnya keputusan untuk berwirausaha merupakan hasil interaksi dari beberapa faktor yaitu karakter kepribadian seseorang dan lingkungannya (Bygrave, 2003). (www.pendidikanekonomi.com).

Hurlock (1999:132) menyatakan bahwa minat merupakan sumber motivasi yang mendorong seseorang untuk melakukan hal yang diimpikan, terutama yang menguntungkan dan mendatangkan kepuasan. Guilford dalam Walgito (1993:24) mengemukakan bahwa minat adalah kecenderungan untuk memperhatikan dan mencari obyek tertentu, perhatian terhadap obyek cenderung mempengaruhi perilaku individu dalam kegiatan. Berdasar beberapa pendapat di atas dapat disimpulkan bahwa minat merupakan kecenderungan seseorang untuk melakukan sesuatu, yang disebabkan karena rasa suka akan sesuatu, menimbulkan rasa tertarik, dan mempengaruhi seseorang untuk berperilaku tertentu. Dalam penelitian ini minat yang dimaksudkan adalah kecenderungan yang tinggi dari seseorang untuk melakukan aktivitas tertentu yang disukai, didasari bakat yang dimiliki, pengalaman dan pada akhirnya mendorong seseorang untuk mengambil keputusan 
berwirausaha. (Pristiana, Kusumaningtyas dan Mujanah : 2003)

Menurut Leonardus Saiman (2014:26), di negara-negara maju, keinginan seseorang untuk menjadi pemimpin terhadap dirinya sendiri cukup besar, berkeinginan sukses tanpa harus dibawah tekanan orang lain, misalnya meskipun perusahaan baru berjalan satu tahun, sudah berusaha keras untuk di waralabakan. Motivasi untuk menjadi seorang waralaba biasanya muncul dengan sendirinya, setelah memiliki bekal cukup untuk mengelola usaha dan siap mental secara total. Ada empat hal yang memotivasi seseorang menjadi wirausaha, yaitu laba, kebebasan, impian personal, dan kemandirian. Laba, disini adalah seseorang dapat menentukan berapa laba yang dikehendaki, keuntungan yang diterima, dan berapa yang akan dibayarkan kepada pihak lain atau pegawainnya. Kebebasan adalah bebas mengatur waktu, bebas dari supervisi, bebas dari tekanan atau intervensi pimpinan dan bebas dari aturan budaya organisasi atau perusahaan. Impian personal aalah bebas mencapai standar hidup yang diharapkan, lepas dari rutinitas kerja yang membosankan, impian untuk menentukan visi dan misi dan impiannya sendiri. Sementara itu Kemandirian adalah memiliki rasa bangga, karena dapat mandiri dalam segala hal, seperti permodalan, mandiri dalam pengelolaan manajemen, mandiri dalam pengawasan, serta menjadi manajer terhadap dirinya sendiri.

Sementara itu menurut Suryana (2013:84), modal motivasi merupakan dorongan atau semangat untuk maju. Motivasi merupakan modal insani bagi setiap orang untuk terus hidup dan maju. Keberhasilan atau kegagalan berwirausaha sangat tergantung kepada tinggi atau rendahnya motivasi wirausahawan. Usaha yang kurang semangat atau penuh dengan keragua akan membuat kegagalan.

Menurut Syamsu Yusuf (2012:23). Lingkungan adalah keseluruhan fenomena (peristiwa, situasi, atau kondisi ) fisik dan alam atau sosial yang memengaruhi atau dipengaruhi perkembangan individu. Keluarga terdiri dari kepala keluarga (ayah), ibu dan anak-anaknya. Keluarga merupakan kelompok sosial pertama dalam kehidupan manusia tempat ia belajar, menyatakan diri sebagai manusia sosial di dalam hubungan interaksi dengan kelompoknya. (Putu Eka Desy Yanti, I Made Nuridja, I Ketut Dunia : 2014)

Ibu adalah wanita yang merupakan bagian dari anggota keluarga primer yang dituntun menjadi seseorang yang multitasking, mampu mengerjakan segala hal 
dalam waktu yang bersamaan, wanita dari mulai pagi sudah harus menyiapkan kebutuhan keluarga, sampai dengan urusan administrasi rumah tangga, seperti mengatur keuangan keluarga setiap bulannya. Secara tidak langsung wanita merupakan manajer bagi sebuah keluarga, yang harus mampu mengatur pendapatan keluarga seimbang dengan pengeluaran. Hal inilah merupakan suatu fenomena modern saat ini, dimana seorang ibu juga dituntut untuk dapat mendukung kebutuhan rumah tangga agar seimbangnya pendapatan dan pengeluaran dalam keluarga, karena tidak cukupnya penghasilan hanya dari suami. Pemberdayaan wanita dalam sebuah keluarga adalah hal yang lazim saat ini agar dapat meningkatkan kesejahteraan keluarga dan juga mensupport perekonomi masyarakat secara umum. Terkadang wanita dipercaya dalam menjalankan dan melanjutkan bisnis keluarga atau orang tua ataupun bermitra dengan suami.

Leidenfrost (1992:115), dalam Pristiana, Kusumaningtyas dan Mujanah (2003) mengatakan bahwa pemberdayaan itu sendiri berarti kekuatan untuk melakukan sesuatu dapat berasal dari pengetahuan baru, ketrampilan yang dimiliki, maupun pengalaman yang diperoleh. Memberdayakan wanita tidak dimaksudkan untuk lebih menambah tanggung jawab wanita tetapi lebih menekankan pada meningkatkan kesadaran wanita dalam hubungan kesetaraan dan struktur yang lebih besar (sosial, ekonomi, politik) dalam kehidupan yang mengancam manusia dan lingkungan.

Sumber modal merupakan hal yang utama bagi seorang wirausaha, wanita yang menjalankan usaha biasanya lebih sulit dalam mendapatkan sumber pendanaan awal atau modal awal, sehingga lebih mengandalkan aset atau tabungan pribadi, seperti yang dikutip dalam Hisrich (2008:83). Pembiayaan suatu usaha dapat diperoleh dari modal sendiri maupun dari modal pinjaman, keduanya tergantung dari jumlah modal yang dibutuhkan dan kebijakan pemilik usaha. Lebih luas lagi mengenai sumber pendanaan usaha menurut Longenecker, dkk 2003 dalam Saiman (2014 : 264), terdapat dua sumber pendanaan usaha, yaitu pendanaan ekuitas atau modal sendiri yang dperoleh dari tabungan individu, teman dan atau saudara, investor perorangan lain, perusahaan lain, perusahaan modal ventura dan penjulan saham. Sumber berikutnya adalah pendanaan dari utang atau pinjaman yang dapat diperoleh dari teman atau saudara, investor perorangan lain, para pemasok bahan 
baku, pemberi pinjaman berbasis aset, bank-bank komersial, program-program yang didukung oleh pemerintah, lembaga-lembaga swadaya masyarakat, perusahaan besar dan perusahaan permodalan ventura.

Perubahan yang terjadi tidak hanya dalam tatanan gender, bahwasanya wanita memiliki kemampuan dalam berwirausaha, tetapi juga wanita dapat merupakan agen perubahan, melalui teknologi. Tekhnologi yang saat ini berkembang dengan pesatnya dapat membantu wanita dalam memudahkan menjalankan bisnisnya. Terutama wanita yang ingin berwirausaha namun tidak ingin meninggalkan keluarganya terlalu lama, dengan menggunakan teknologi dapat menjadi pilihan yang tepat. Perkembangan media sosial dan kecanggihan technologi dapat menjadi salah satu faktor yang mendorong wanita dalam menjadi wiruasaha.

Akhirnya, inovasi dalam bisnis melalui Informasi Komunikasi (TIK) memainkan peran penting dalam mendukung perempuan pengusaha di bisnis dengan memperoleh struktur biaya rendah dan mencapai hasil yang lebih tinggi per pelanggan (Marlin \& Wright, 2005) dalam Syed Shah Alam (2010).

Berdasarkan teori-teori dan hasil penelitian terdahulu seperti diuraikan sebelumnya, maka peneliti menggambarkan model penelitian sebagai berikut : Gambar Model Penelitian

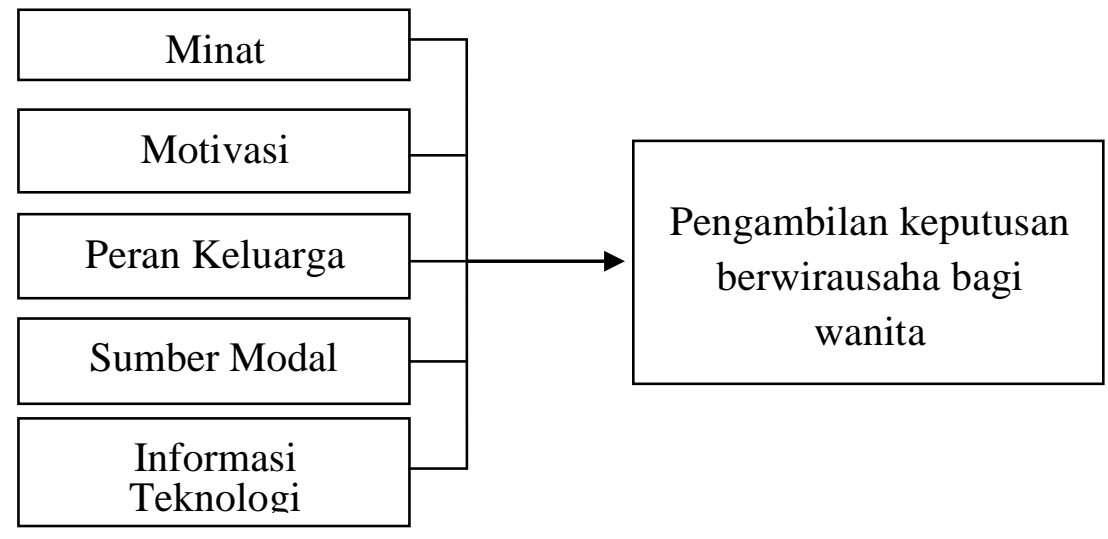

\section{METODOLOGI}

Objek dalam penelitian ini adalah wanita muslim yang sudah menjalankan usaha dengan kategori usaha kecil dan menengah diwilayah Tanggerang Selatan pada akhir tahun 2013 sampai dengan awal 2014, dalam kurun waktu 3 bulan. Populasi pada penelitian ini adalah wanita Muslim dari wilayah Tanggerang Selatan yang kemudian diambil 60 orang menjadi sampel, karena menurut roscoe (1982:253) dalam Sugiyono (2011:91) ukuran yang layak dalam penelitian adalah antara 30 
sampai dengan 500. Pengambilan sampel dilakukan dengan metode purposive sampling yang merupakan salah satu metode non probability sampling, teknik ini merupakan penentuan sampel dengan pertimbangan tertentu, yaitu sampel merupakan wanita muslim yang berdomisili di wilayah Tanggerang Selatan dan sudah memiliki usaha minimal 6 bulan.

Penelitian ini menggunakan dua jenis data, yaitu data primer dan data sekunder. Data primer adalah data yang diperoleh dari hasil penyebaran kuesioner, sedangkan data sekunder diperoleh dari studi pustaka beberapa buku, jurnal, internet dan sumber lainnya yang dapat dipercaya. Penelitian ini menggunakan kuesioner dengan skala likert, dimana variabel yang akan diukur dijabarkan menjadi indikator variabel bergradasi 5 dalam bentuk pilihan ganda atau pertanyaan tertutup. (Sugiyono 2011:94) Langkah selanjutnya adalah dilakukan uji reliable, yang merupakan uji sejauh mana suatu hasil pengukuran relatif konsisten jika pengukuran diulangi dua kali atau lebih. Dilanjutkan dengan uji validitas, yang menunjukkan sejauh mana suatu alat ukur mampu mengukur apa yang ingin diukur. (Umar 2000: 179).

Metode analisis dalam penelitian ini adalah menggunakan analisis faktor, menurut Suliyanto (2004:125) proses analisis faktor didasarkan pada matriks korelasi antara variabel satu dengan variabel yang lain, untuk memperoleh analisis faktor yang semua variabel-variabelnya harus berkorelasi. Untuk menguji ketepatan dalam model faktor, uji statistik yang digunakan adalah Barletts test Sphericity dan kaiser Mayer Olkin (KMO) untuk mengetahui kecukupan sampelnya. KMO uji yang nilainya berkisar antara 0 sampai 1 mempertanyakan kelayakan analisis faktor. Apabila nilai indeks tinggi berkisar antara 0.5 sampai 1.0 analisis faktor layak di lakukan. Sebaliknya, jika nilai KMO di bawah 0.5 analisis faktor tidak layak dilakukan. Selanjutnya dilakukan uji MSA Uji Measure of sampling Adequency (MSA), pada uji MSA angkanya haruslah berada pada 0 sampai 1 . 
Tabel

Ukuran ketepatan KMO

\begin{tabular}{|c|c|}
\hline Ukuran KMO & Rekomendasi \\
\hline 0.9 & Sangat setuju \\
\hline 0.8 & Setuju \\
\hline 0.7 & Ragu-ragu \\
\hline 0.6 & Tidak setuju \\
\hline 0.5 & Sangat tidak setuju \\
\hline$<0.5$ & ditolak \\
\hline
\end{tabular}

Suliyanto (2004:125)

Model analisis faktor dinyatakan dengan rumus sebagai berikut :

$$
\mathrm{Xi}=\mathrm{Aij}+\mathrm{Ai} 2 \mathrm{~F} 2+\mathrm{AiF} 3
$$
$+\mathrm{AimFm}+\mathrm{ViUi}$

Dimana :

Xi : Variabel standar yang ke-i

Aij : Koefisien multiple regresi standar dari variable ke-I pada common factor $\mathrm{j}$

F : Common factor

Vi : Koefisien regresi berganda standar dari variable ke-i pada faktor unik-i

Ui : Faktor unik variabel-i

m : Banyaknya common factor

\section{PEMBAHASAN}

Hal pertama yang harus dilakukan dalam analisis faktor adalah dengan melakukan KMO and Barlett's test. Pengujian ini dilakukan untuk menilai variabel mana saja yang layak untuk dimasukan kedalam analisis selanjutnya.

Tabel 2

Uji KMO and Bartlett's Test

\begin{tabular}{|c|r|r|}
\hline \multicolumn{2}{|c|}{ Kaiser-Meyer-Olkin Measure of Sampling } &, 614 \\
& Adequacy. & 942,020 \\
Bartlett's Test & Approx. Chi-Square & 435 \\
of Sphericity & df &, 000 \\
\hline
\end{tabular}

Sumber : Data primer yang telah diolah, 2014 
Dari hasil uji KMO and Bartlett's Test diatas, diperoleh nilai KMO-MSA (kaisermeyer-olkin measure of sampling adequacy) sebesar 0,614 dengan tingkat signifikansi 0,000. Oleh karena angka tersebut diatas $0,5(0,614>0,5)$ dan signifikansi jauh berada dibawah $0,05(0,000<0,05)$, maka variabel dan sampel yang ada secara keseluruhan dapat dianalisis lebih lanjut.

Tabel

Uji Measures of Sampling Adequacy (MSA)

\begin{tabular}{|c|c|c|}
\hline Pernyataan & MSA & Ket. \\
\hline Memiliki tantangan dari dalam diri sendiri & 0,674 & Valid \\
\hline Stress dengan pekerjaan yang tetap & 0,515 & Valid \\
\hline Ingin mendapatkan variasi dan pengalaman dalam bekerja & 0,665 & Valid \\
\hline Ingin mencoba produk dan ide bisnis baru & 0,686 & Valid \\
\hline Ingin meningkatkan kesenangan pribadi & 0,744 & Valid \\
\hline $\begin{array}{l}\text { Ingin lebih baik menggunakan kemampuan dan keterampilan diri } \\
\text { sendiri }\end{array}$ & 0,715 & Valid \\
\hline Agar menghasilkan lebih banyak uang dan menjadi lebih makmur & 0,747 & Valid \\
\hline Agar dapat meningkatkan status social & 0,506 & Valid \\
\hline Membutuhkan uang lebih untuk bertahan hidup & 0,377 & Tidak Valid \\
\hline Lebih mau memimpin daripada dipimpin orang lain & 0,510 & Valid \\
\hline Dapat mengontrol waktu dan jam kerja sendiri & 0,708 & Valid \\
\hline Ingin tinggal dan bekerja dilokasi yang sama & 0,499 & Tidak Valid \\
\hline Menjadi tradisi keluarga untuk meneruskan usaha keluarga & 0,311 & Tidak Valid \\
\hline Keluarga sangat mendukung untuk menjadi wirausaha & 0,621 & Valid \\
\hline Suami berperan daam menjalankan usaha & 0,357 & Tidak Valid \\
\hline Tulang punggung keluarga & 0,526 & Valid \\
\hline Memberikan sumber pendapatan lain untuk keluarga & 0,440 & Tidak Valid \\
\hline Berwirausaha karena dipengaruhi anggota keluarga & 0,351 & Tidak Valid \\
\hline Memiliki sumber dana modal sendiri dalam wirausaha & 0,605 & Valid \\
\hline Keluarga memberikan modal usaha & 0,377 & Tidak Valid \\
\hline Mendapatkan kemudahan kredit usaha dari bank & 0,447 & Tidak Valid \\
\hline
\end{tabular}




\begin{tabular}{|l|c|c|}
\hline Mendapatkan bantuan modal dari rekan & 0,291 & Tidak Valid \\
\hline Mendapatkan bantuan dari lembaga swadaya masyarakat & 0,424 & Tidak Valid \\
\hline Mendapatkan bantuan dari pemerintah & 0,605 & Valid \\
\hline Fasilitas internet mempermudah dalam berwirausaha & 0,740 & Valid \\
\hline Handphone mempermudah dalam menjalankan usaha & 0,723 & Valid \\
\hline Sosial media mempermudah dalam memasarkan usaha & 0,723 & Valid \\
\hline Informasi teknologi dapat memperluas jaringan usaha & 0,770 & Valid \\
\hline $\begin{array}{l}\text { Penggunaan teknologi informasi mengurangi biaya usaha } \\
\text { Sangat bergantung terhadap teknologi informasi dalam menjalankan } \\
\text { usaha }\end{array}$ & 0,739 & Valid \\
\hline
\end{tabular}

Sumber : Data primer yang telah diolah, 2014

Dari ke 30 butir pernyataan yang digunakan, terdapat 10 pernyataan yang tidak memenuhi batas 0,5 yaitu pernyataan membutuhkan uang lebih untuk bertahan hidup dengan nilai MSA sebesar 0,377, ingin tinggal dan bekerja dilokasi yang sama dengan nilai MSA 0,499, menjadi tradisi keluarga untuk meneruskan usaha keluarga dengan nilai MSA 0,311, suami berperan daam menjalankan usaha dengan nilai MSA 0,357, memberikan sumber pendapatan lain untuk keluarga dengan nilai MSA 0,440, berwirausaha karena dipengaruhi anggota keluarga dengan nilai MSA 0,351, keluarga memberikan modal usaha dengan nilai MSA 0,377, mendapatkan kemudahan kredit usaha dari bank dengan nilai MSA 0,447, mendapatkan bantuan modal dari rekan dengan nilai MSA 0,291, mendapatkan bantuan dari lembaga swadaya masyarakat dengan nilai MSA 0,424. Karena nilai kesepuluh pernyataan tersebut berada dibawah 0,5, maka kesepuluh pernyataan tersebut dianggap tidak valid sehingga harus dikeluarkan dan pengujian diulang kembali. Penulis memilih perwakilan dari masingmasing variabel dengan nilia MSA yang paling rendah diantara sepuluh pernyataan tersebut untuk dikeluarkan, yaitu pernyataan membutuhkan uang lebih untuk bertahan hidup dengan nilai MSA 0,377, menjadi tradisi keluarga untuk meneruskan usaha keluarga dengan nilai MSA 0,311 dan keluarga memberikan modal usaha dengan nilai MSA 0,377. 
Setelah ke 3 pernyataan tersebut dikeluarkan dari faktor, maka langkah selanjutnya adalah melakukan pengujian ulang analisis faktor terhadap 27 variabel yang masih tersisa.

\section{Tabel}

Uji KMO and Bartlett's Test

\begin{tabular}{|c|c|}
\hline 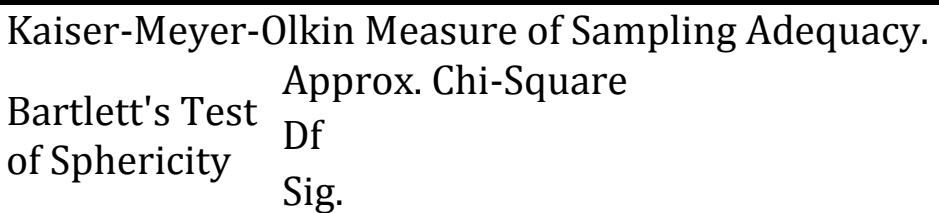 & $\begin{array}{r}, 677 \\
823,011 \\
351 \\
, 000\end{array}$ \\
\hline
\end{tabular}

Sumber : Data primer SPSS yang telah diolah, 2014

Pada tabel KMO and bartlett's test diatas, dapat dilihat bahwa nilai KMO-MSA mengalami kenaikan sebesar 0,063 yaitu dari 0,614 menjadi 0,677 dengan tingkat signifikansi tetap $(0,000)$. Hal ini disebabkan karena ada proses penghilangan 3 variabel yang memiliki nilai MSA dibawah 0,5. Oleh karena nilai MSA sudah diatas 0,5 dan signifikansi jauh berada dibawah 0,05 $(0,000<0,05)$, maka variabel dan sampel yang ada secara keseluruhan dapat dianalsis lebih lanjut. Untuk angka MSA dalam tabel anti image matric pada anti image correlation dapat dilihat pada tabel ini.

Tabel

Uji Measures of Sampling Adequacy (MSA)

\begin{tabular}{|l|c|c|}
\hline \multicolumn{1}{|c|}{ Pernyataan } & MSA & Ket. \\
\hline Memiliki tantangan dari dalam diri sendiri & 0,698 & Valid \\
\hline Stress dengan pekerjaan yang tetap & 0,671 & Valid \\
\hline Ingin mendapatkan variasi dan pengalaman dalam bekerja & 0,698 & Valid \\
\hline Ingin mencoba produk dan ide bisnis baru & 0,793 & Valid \\
\hline Ingin meningkatkan kesenangan pribadi & 0,785 & Valid \\
\hline $\begin{array}{l}\text { Inginlebih baik menggunakan kemampuan dan ketrampilan } \\
\text { diri sendiri }\end{array}$ & 0,751 & Valid \\
\hline $\begin{array}{l}\text { Agar menghasilkan lebih banyak uang dan menjadi lebih } \\
\text { makmur }\end{array}$ & 0,796 & Valid \\
\hline Agar dapat meningkatkan status social & 0,514 & valid \\
\hline Lebih mau memimpin daripada dipimpin oranglain & 0,723 & Valid \\
\hline Dapat emngontrol waktu dan jam kerja sendiri & 0,708 & Valid \\
\hline Ingin tinggal dan bekerja dilokasi yang sama & 0,432 & Tidak valid \\
\hline
\end{tabular}




\begin{tabular}{|l|c|c|}
\hline Keluarga sangat mendukung untuk menjadi wirausaha & 0,669 & Valid \\
\hline Suami berperan daam menjalankan usaha & 0,319 & Tidak valid \\
\hline Tulang punggung keluarga & 0,567 & Valid \\
\hline Memberikan sumber pendapatan lain untuk keluarga & 0,405 & Tidak valid \\
\hline Berwirausaha karena dipengaruhi anggota keluarga & 0,457 & Tidak valid \\
\hline Memiliki sumber dana modal sendiri dalam wirausaha & 0,630 & Valid \\
\hline Mendapatkan kemudahan kredit usaha dari bank & 0,374 & Tidak valid \\
\hline Mendapatkan bantuan modal dari rekan & 0,430 & Tidak valid \\
\hline Mendapatkan bantuan dari lembaga swadaya masyarakat & 0,523 & Valid \\
\hline Mendapatkan bantuan dari pemerintah & 0,539 & Valid \\
\hline Fasilitas internet mempermudah dalam berwirausaha & 0,756 & Valid \\
\hline Handphone mempermudah dalam menjalankan usaha & 0,804 & Valid \\
\hline Sosial media mempermudah dalam memasarkan usaha & 0,710 & Valid \\
\hline Informasi teknologi dapat memperluas jaringan usaha & 0,753 & Valid \\
\hline Penggunaan teknologi informasi mengurangi biaya usaha & 0,812 & Valid \\
\hline $\begin{array}{l}\text { Sangat bergantung terhadap teknologi informasi dalam } \\
\text { menjalankan usaha }\end{array}$ & 0,767 & Valid \\
\hline Sumber : Data primer SPSS yang telah dialah, 2014 & & \\
\hline
\end{tabular}

Sumber : Data primer SPSS yang telah diolah, 2014

Dari 27 variabel yang direduksi hanya terdiri atas 9 faktor saja, yaitu:

a. Faktor ke-1 didominasi oleh:

1) Fasilitas internet mempermudah dalam berwirausaha karena variabel ini memiliki nilai loading terbesar pada komponen faktor ke-1 yaitu sebesar 0,878. Maka variabel ini masuk kedalam faktor ke-1.

2) Sosial media mempermudah dalam memasarkan usaha, karena variabel ini memiliki nilai loading terbesar pada komponen faktor ke-1 yaitu sebesar 0,905. Maka variabel ini masuk kedalam faktor ke-1.

3) Informasi teknologi dapat memperluas jaringan usaha, karena variabel ini memiliki nilai loading terbesar pada komponen faktor ke-1 yaitu sebesar 0,901. Maka variabel ini masuk kedalam faktor ke-1. 
4) Penggunaan teknologi informasi mengurangi biaya usaha, karena variabel ini memiliki nilai loading terbesar pada komponen faktor ke-1 yaitu sebesar 0,800. Maka variabel ini masuk kedalam faktor ke-1. Variabel ini memiliki nilai loading terbesar pada komponen faktor ke-1 yaitu sebesar 0,627. Maka variabel ini masuk kedalam faktor ke-1.

b. Faktor ke-2 didominasi oleh:

1) Memiliki tantangan dari dalam diri sendiri karena variabel ini memiliki nilai loading terbesar pada komponen faktor ke-2 yaitu sebesar 0,798. Maka variabel ini masuk kedalam faktor ke-2.

2) Ingin mendapatkan variasi dan pengalaman dalam bekerja, karena variabel ini memiliki nilai loading terbesar pada komponen faktor ke-2 yaitu sebesar 0,653. Maka variabel ini masuk kedalam faktor ke-2.

3) Ingin mencoba produk dan ide bisnis baru, karena variabel ini memiliki nilai loading terbesar pada komponen faktor ke-2 yaitu sebesar 0,654. Maka variabel ini masuk kedalam faktor ke-2.

4) Handphone mempermudah dalam menjalankan usaha, karena variabel ini memiliki nilai loading terbesar pada komponen faktor ke-2 yaitu sebesar 0,161. Maka variabel ini masuk kedalam faktor ke-2.

c. Faktor ke-3 didominasi oleh:

1) Stress dengan pekerjaan yang tetap, karena variabel ini memiliki nilai loading terbesar pada komponen faktor ke-3 yaitu sebesar 0,751. Maka variabel ini masuk kedalam faktor ke-3.

2) Ingin meningkatkan kesenangan pribadi, karena variabel ini memiliki nilai loading terbesar pada komponen faktor ke-3 yaitu sebesar 0,620. Maka variabel ini masuk kedalam faktor ke-3.

3) Agar dapat meningkatkan status social, karena variabel ini memiliki nilai loading terbesar pada komponen faktor ke-3 yaitu sebesar 0,539. Maka variabel ini masuk kedalam faktor ke-3.

4) Sangat bergantung terhadap teknologi informasi dalam menjalankan usaha, karena variabel ini memiliki nilai loading terbesar pada komponen faktor ke-3 yaitu sebesar 0,332. Maka variabel ini masuk kedalam faktor ke-3. 
d. Faktor ke-4 didominasi oleh:

1) Ingin lebih baik menggunakan kemampuan dan ketrampilan diri sendiri, karena variabel ini memiliki nilai loading terbesar pada komponen faktor ke-4 yaitu sebesar 0,526. Maka variabel ini masuk kedalam faktor ke-4.

2) Dapat mengontrol waktu dan jam kerja sendiri, karena variabel ini memiliki nilai loading terbesar pada komponen faktor ke-4 yaitu sebesar 0,681. Maka variabel ini masuk kedalam faktor ke-4.

3) Ingin tinggal dan bekerja dilokasi yang sama, karena variabel ini memiliki nilai loading terbesar pada komponen faktor ke-4 yaitu sebesar 0,819. Maka variabel ini masuk kedalam faktor ke-4.

e. Faktor ke-5 didominasi oleh:

1) Mendapatkan bantuan modal dari rekan, karena variabel ini memiliki nilai loading terbesar pada komponen faktor ke-5 yaitu sebesar 0,258. Maka variabel ini masuk kedalam faktor ke-5.

2) Mendapatkan bantuan dari lembaga swadaya masyarakat, karena variabel ini memiliki nilai loading terbesar pada komponen faktor ke-5 yaitu sebesar 0,829. Maka variabel ini masuk kedalam faktor ke-5.

3) Mendapatkan bantuan dari pemerintah, karena variabel ini memiliki nilai loading terbesar pada komponen faktor ke-5 yaitu sebesar 0,776. Maka variabel ini masuk kedalam faktor ke-5.

f. Faktor ke-6 didominasi oleh:

1) Agar menghasilkan lebih banyak uang dan menjadi lebih makmur, karena variabel ini memiliki nilai loading terbesar pada komponen faktor ke-6 yaitu sebesar 0,599. Maka variabel ini masuk kedalam faktor ke-6.

2) Tulang punggung keluarga, karena variabel ini memiliki nilai loading terbesar pada komponen faktor ke-6 yaitu sebesar 0,808. Maka variabel ini masuk kedalam faktor ke-6.

3) Memiliki sumber dana modal sendiri dalam wirausaha, karena variabel ini memiliki nilai loading terbesar pada komponen faktor ke-6 yaitu sebesar 0,501. Maka variabel ini masuk kedalam faktor ke-6. 
g. Faktor ke-7 didominasi oleh:

1) Lebih mau memimpin daripada dipimpin oranglain, karena variabel ini memiliki nilai loading terbesar pada komponen faktor ke-7 yaitu sebesar 0,781. Maka variabel ini masuk kedalam faktor ke-7.

h. Faktor ke-8 didominasi oleh:

1) Keluarga sangat mendukung untuk menjadi wirausaha, karena variabel ini memiliki nilai loading terbesar pada komponen faktor ke-8 yaitu sebesar 0,449. Maka variabel ini masuk kedalam faktor ke-8.

2) Suami berperan daam menjalankan usaha, karena variabel ini memiliki nilai loading terbesar pada komponen faktor ke-8 yaitu sebesar 0,643. Maka variabel ini masuk kedalam faktor ke-8.

3) Berwirausaha karena dipengaruhi anggota keluarga, karena variabel ini memiliki nilai loading terbesar pada komponen faktor ke-8 yaitu sebesar 0,685. Maka variabel ini masuk kedalam faktor ke-8.

4) Mendapatkan kemudahan kredit usaha dari bank, karena variabel ini memiliki nilai loading terbesar pada komponen faktor ke-8 yaitu sebesar 0,621. Maka variabel ini masuk kedalam faktor ke-8.

i. Faktor ke-9 didominasi oleh:

1) Memberikan sumber pendapatan lain untuk keluarga, karena variabel ini memiliki nilai loading terbesar pada komponen faktor ke-9 yaitu sebesar 0,916. Maka variabel ini masuk kedalam faktor ke-9.

\section{KESIMPULAN}

Berdasarkan analisis dan pembahasan dari data tentang penilaian responden terhadap analisis faktor-faktor yang mempengaruhi keputusan wanita muslim berwirausaha di Tanggerang Selatan, maka dapat ditarik kesimpulan, melalui analisis faktor dapat diperoleh sembilan faktor yang berpengaruh paling dominan terhadap keputusan wanita muslin berwirausaha di wilayah Tanggerang Selatan. Adapun faktor-faktor tersebut adalah :

1. Faktor pertama di dominasi oleh fasilitas internet, sosial media, informasi teknologi memperluas jaringan dan penggunaan informasi teknologi 
mengurangi biaya usaha para wanita pengusaha muslim di wilayah tanggerang selatan dalam berpromosi.

2. Faktor kedua didominasi oleh tantangan dari dalam diri sendiri, ingin mendapatankan pengalaman dalam bekerja, ingin mencoba ide bisnis baru dan penggunaan telepon selular memudahkan mereka menjalankan usahanya.

3. Faktor ketiga didominasi oleh para wanita ini berwirausaha untuk menghindari stress dari pekerjaan tetap, mereka ingin meningkatkan kesenangan pribadi, mereka juga ingin meningkatkan status sosial dan lagi lagi mereka sangat bergantung dengan kemajuan informasi teknologi dalam menjalankan usahanya.

4. Faktor keempat didominasi keinginan untuk menggunakan kemampuan dan ktrampilan diri sendiri, mereka juga dapat mengontrol diri sendiri dengan jam kerja yang lebih fleksibel, dan mereka ingin bekerja dilokasi mereka tinggal, agar bisa dekat dengan keluarga.

5. Faktor kelima didominasi mereka berwirausaha juga didukung oleh bantuan modal dari rekan, bantuan dari swadaya masyarakat, dan adanya peluang bantuan dari pemerintah.

6. Faktor keenam didominasi oleh keinginan para wanita muslim ini untuk menghasilkan lebih banyak uang dan menjadi lebih makmur, mereka juga merupakan tulang punggung keluarga, dan adanya sumber keuangan peribadi yang dapat mendukung jalannya bisnis.

7. Faktor ketujuh didominasi oleh keinginan untuk memimpin usaha nya sendiri, daripada bekerja untuk orang lain yang akan dipimpin oleh orang lain.

8. Faktor kedelapan didominasi oleh dukungan yang diperoleh dari keluarga, suami, anggota keluarga lainnya dan juga dukungan dari kemudahan kredit dari bank untuk melanjutkan kelangsungan bisnis.

9. Faktor kesembilan didominasi oleh keinginan untuk mendapatkan sumber pendapatan lainnya selain dari suami.

\section{REFERENSI}

Alma, Buchari. 2001. Kewirausahaan, Alfabeta, Bandung

Hisrich, Robert D, Peters, Michaelp, dan Sheperd Dean A.2008. Entrepreneurship, edisi ketujuh, Salemba Empat, Jakarta 
Inriantoro, Nur dan Supomo, Bambang. 1998. Metodelogi Penelitian Bisnis, UGM, Yogjakarta

Kasmir. 2008. Kewirausahaan, RajaGrafindo Perkasa, Jakarta

Kelana Muslim. 2008. Muhammad SAW is A Great Entrepreuner, Dinar Publishing, Bandung

Prijambodo. 2000. Kewirausahaan, STIA LAN Press

Pristiana, Ulfi, Kusumaningtyas, Amiartuti dan Mujanah, Sri. 2009. Faktor-faktor Yang Mempengaruhi Pengambilan Keputusan Wanita Berwirausaha di Surabaya

Saiman, Leonardus. 2014. Kewirausahaan; Teori, Praktek, dan kasus-kasus, Edisi kedua, Salemba Empat, Jakarta

Shah Alam, Syed, Mohd Jani, Mohd Fauzi, dan Omar, Nor Asiah. 2011. An Empirical Study of Success Factors of Women Entrepreuners in Southern Region in Malaysia. International Journal of Economics and Finance.

Siswanto, Victorinus Aries. 2009. Studi Peran Perempuan Dalam Pengembangan Usaha Kecil Menengah Melalui Teknologi Informasi di Kota Pekalongan. Jurnal Dinamika Informatika.

Sugiyono. 2011. Metode Penelitian Kuantitatif, Kualitatif dan R\&D, Alfabeta, Bandung Suryana. 2013. Kewirausahaan; Kiat dan Proses Menuju Sukses, Salemba Empat, Jakarta

Tim Multitama Communications. 2006. Islamic Business Strategy for Entrepreunership, Zikrul Hakim, Jakarta

Umar, Husein. 2000. Riset Pemasaran \& Perilaku Konsumen, Gramedia, Jakarta

Yanti Desy, Putu Eka, Nuridja, I Made dan Dunia, I Ketut. 2014. Pengaruh Keluarga Terhadap Berwirausaha Siswa Kelas XI SMK Negeri 1 Singaraja.

Zimmerer, Thomas W, dan Scarborough, Norman M. 2004. Pengantar Kewirausahaan dan Manajemen Bisnis Kecil, edisi kedua, Indeks, Jakarta

Zimmerer, Thomas W, Scarborough, Norman M. Dan Wilson, Doug. 2008. Pengantar Kewirausahaan dan Manajemen Usaha Kecil, edisi kelima, Salemba EMpat, Jakarta

Ziyad, Ichwan . 2013. Siti Khadijah, Business Woman Paling Terkenal di Dunia, http://sekolahumarusman.com/siti-khodijah-business-woman-paling-terkenal-didunia/ 